\title{
Perspective Directions of Development of Innovative Structures on the Basis of Modern Technologies
}

\author{
Alovsat Garaja Aliyev ${ }^{a^{*}}$, Roza Ordukhan Shahverdiyeva ${ }^{\mathrm{b}}$ \\ ${ }^{a, b}$ Institute of Information Technology of Azerbaijan National Academy of Sciences AZ1 141, Azerbaijan \\ Republic, Baku, B.Vahabzade str., $9 A$
}

Received: 23 March 2018; Accepted: 19 April 2018; Published: 08 July 2018

\begin{abstract}
The article analyzes the need to create innovative manufacturing enterprises in modern conditions, and justifies their role in the development of society. The principles, priorities and strategic requirements to the innovative manufacturing enterprises in the process of economic development are analyzed. International, regional and local recommendations for the formation of innovative enterprises structures are generalized. Perspective applications of components of the fourth industrial revolution are considered. Ways of improving the innovation infrastructure and environment are examined from the scientific and theoretical and methodological point of view. Priorities, mechanisms, elements of communication, the parameters and criteria for the management of innovative manufacturing enterprises structures are identified.
\end{abstract}

Index Terms: Innovative economy, innovative manufacturing enterprises, innovative structures, fourth industrial revolution, technology park, high-tech park, the future of enterprise.

(C) 2018 Published by MECS Publisher. Selection and/or peer review under responsibility of the Research Association of Modern Education and Computer Science

\section{Introduction}

Advanced economy of the modern period is characterized with knowledge, new technologies and innovations. Thus, we can assume that high technologies will form the modern development basis of country's economy. Currently, highest technologies that allow generating competitive products encompass all fields of developed countries' economies, and provide the formation of economy established on the basis of generation, distribution and use of the new stage of information society - knowledge. Dynamics of scientific and innovative development is determined upon the organization process of transfer of knowledge and technologies. The elimination of underdevelopment in manufacturing and technology application fields of the country is one

* Corresponding author.

E-mail address: alovsat_qaraca@mail.ru, shahverdiyevar@gmail.com 
of targets in order to increase competitiveness of national enterprises and economy. The most important condition to be considered while developing development strategy of enterprises is the application of scientific novelties and science-based technologies [1]. The reason of economic development of Azerbaijan during the last decade is due to implementation of economic reforms supported by scientific basis. One of the most important duties is to accelerate the socioeconomic development using innovative and creative tools. Increasing intensiveness of innovative processes is one of the important directions of changes occurring in the global economic system. In developed countries, $75-90 \%$ of GDP growth and 10\% of GDP growth in CIS countries is provided by the innovation sector [1]. CIS countries lose billions of resources as a result of recession in the innovation field. From this standpoint, it is important to achieve innovative economic growth for entry of the country into new foreign markets. In such conditions, serious attention must be paid to manufacturing and service structures, and the improvement of their innovative activity [2]. Relevant requirements and priorities have been created for the development of relevant entities. Strategic requirements and principals for innovative structures and systems have been indicated in accordance with determined duties. At the same time, possible control mechanisms' development directions have been considered in order to regulate and stimulate innovation activities. For this reason, analytic and comparative analysis of international recommendations, instructions and agreements existing in that field is necessary, in order to improve the control mechanisms formed in order to stimulate, generalize and scientifically justify current and perspective requirement set towards innovation structures of different character, assignment and level, as well as their stimulation and regulation of their activity in integrated manner.

Perspective applications of components of the IV industrial revolution in innovative enterprises. The level of scientific and technological development shows that the main economic sectors are in fact industrialized. This is the transformation of the economy at industrial facilities. The experience of developed countries proves that their success is based on intellectual potential, technological progress, development of science and level of education. In the coming years, robotics, autonomous vehicles, artificial intelligence, computer training, modern computer, network technologies, information technologies, new materials, and biotechnology will become more accessible. Within the framework of the fourth industrial revolution the following tendencies are being developed: 1)artificial intelligence and machine learning, 2)the future of drones and tomorrow's airspace, 3)robotization in different areas and rapid spread in human life, 4)Internet of things technologies, 5)"3D printing" and products, nanotechnology, biotechnology, quantum calculations, energy reserve, increase of use of renewable energy sources, 6)creation of autonomous vehicles, etc.

The fourth industrial revolutionary initiative is aimed at increasing the competitiveness of the industry through the application of cyberphysical systems to production processes. The fourth industrial revolution is based on automated and robotic tools at production and management. The main feature of this industrial revolution is its digitalization. The current period of the IV industrial revolution can be regarded as a threshold period or a transition period. In this period, the economy develops on the basis of innovations, knowledge and new technologies. The effects of the fourth industrial revolution on the formation of the information economy and the perspective development of innovative structures are being studied.

\section{Organizing Innovation Activity in International Economic Agencies and Enterprises}

There are many international economic agencies worldwide that are engaged in problems of innovative enterprises, entrepreneurship and innovation technologies. The United Nations University - Maastricht Economic and Social Research Institute on Innovation and Technology (UNU-MERIT) has conducted researches in economic, innovation and innovative entrepreneurship fields. Role of innovations in economic development and factors of innovative environment have been researched in those researches [3]. United Nations Economic and Social Council (ECOSOC) serves as the central forum acting in innovation thinking development field and supporting continuous economic development [4]. ECOSOC has several regional branches in Africa, Asia, Europa, Latin America, Asia and Pacific Ocean basin. Event organized on "Innovation and technology for development of knowledge-based economy in Arab region" conducted in 
Amman, Jordan in 2015 by the technological development commission can be sited among regular actions taken by them. Topical issues, such as trade and development, information economy, e-commerce innovation and broadening of application of technologies, can be found on the official web site of United Nations Conference on Trade and Development (UNCTD). Besides, UNCTD continues its research in fields such as creative economy, industry, technologic innovations, e-commerce, investments, ICT, activities of innovative structures. Statistical indicators of UNCTD can be found on its web-portal. These indicators include 1) international trade, 2) economic growth,3) foreign investments, 4) information economy etc. [5]. Overall, currently, there are 194 member states of UN conference on Trade and Development. Azerbaijan is among top 20 member states. UNCTD has structural divisions such as 1) trade and development committee, 2) investment, entrepreneurship and development committee, 3) science and technology committee for development [5]. UNCTD has conducted many international conferences in different years. UN Special Programme is a joint effort of UN and Central Asian countries going through transition phase. Main objectives and activity directions of the programme were expressed in Tashkent Declaration in 1998. The objective of the program is to support and encourage integration of regional countries, attraction of internal and external resources to financing of priorities, more active application of standards and norms of Economic and Social Commission for Asia and Pacific and The United Nations Economic Commission for Europe (UNECE). Azerbaijan was accepted to the 4th session of Regional Consultation Commission conducted in Bishkek city in 2002 [6]. Another important agency - Organization for Democracy and Economic Development (GUAM), was created in 2006. The main objectives of the organization is the recognition of democratic value, providing the rule of law and human rights, sustainable development, deepening European integration in order to create a general security environment, also broadening of economic and humanity cooperation. Let's remind that UN Development Programme (UNDP) has adopted "Knowledge control strategy in 2014-2017 years". Moreover, following can be sited among important annual reports and events conducted by UN DP [7]: 1) Annual summary of innovative enterprises for the year of 2014 2) Discussion report on "Innovation monitoring and assessment" prepared and knowledge and innovation group and conducted in 2013,3) "Knowledge and innovation report" for 2011- 2013 years for Europe and CIS region [7]. International Association Of Organization Innovation (IAOI) was established in Florida, USA in 2005 [8]. IAOI is a professional organization specialized in management, development of innovative products, services and technologies and performance of engineering works. The mission of the organization is to increase the role of innovations and new technologies in the operations of the enterprises, create new enterprises by strengthening international relations, and achieve more efficient results in their operations. IAOI International Journal publishes over 300 articles on innovations [8]. IAOI conducted the 12th European conference on "Creativity and innovation" in Portugal. This organization also annually conducts international conferences in South-Asian countries. One of those conferences was held in Indonesia in 2015, and covered topics such as: 1) innovation, 2) innovation, knowledge and technologic management, 3) e-innovation, 4) innovation entrepreneurship, 5) globalization and economy, 6) information management and e-business [9]. The European Association for the Transfer of Technologies, Innovation and Industrial Information (TII) is located in Luxembourg. Its mission is to create a global society to support development of regional innovations and transfer of technologies [10]. TII held an annual report conference on "Innovation: Challenges, Needs and Skills of the New Innovation Era" with participation of 31 countries in Dusseldorf, Germany, in 2010. The head office of International Association of Scientific Innovation and Research (IASIR) is located in Georgia, USA, with regional offices in India, Canada, Australia, Germany and Netherlands [11]. IASIR is a non-commercial international innovative organization. The mission of IASIR is to accelerate development of science and scientific-innovation researches, create mutual relations in different fields of management and engineering, as well as among scientists and specialists, to conduct experience exchange and assist in development of innovation technologies. The objective of "Technopol-Moscow" Scientific-Technical Association (TMSTA) is to develop scientific-technical and intellectual potential. Its objective is to assist local and foreign companies in transfer of technologies [12]. Furthermore, there are agencies connecting and regulating the activities of innovation structures worldwide, in a certain form. The principal agency - International Association of Scientific Parks (IASP) was established in 
1984. [13]. With its head office located in Spain, IASP has 396 members, 128000 companies, 73 member states and 6 regional divisions. Some other international organizations are also engaged in regulation of activities of innovative structures: 1) Association of University Research Parks, 2) Asian Science Parks Association, 3) The United Kingdom Science Park Association, 4) World Technopolis Association, 5) Russia Technopolis Association etc. Each organization conducts relevant works with innovation enterprises in accordance with its objectives. International organizations, such as World Alliance for Science and Technology Parks Association (WASTPA) [14], and National Association for Business Incubators (NABI), conduct analysis and accounting of technoparks around the world [15]. It must be noted that, in its turn, NABI is also a member of World Alliance for Science and Technology Parks Association (WASTPA). WASTPA is a global network uniting major science park and innovation-type business incubators. Recommendations of European Union Committee for Innovative Production Structures As noted above, under current conditions, specialized agencies of the UN, and several regional organizations provide their recommendations and proposals to enterprises and structures regarding their re-establishment and improvement of their activities. One of the most important recommendations on innovative structures belongs to the European Commission. Priority fields of cooperation among many countries within the European Union include important directions, such as diversification of economy, in order to reduce differences among territories, supporting development of regions to provide more balanced and comprehensive development, development of education systems meeting the working power needs in the labor market etc. One of such important directions is the concept of "Factories of Future" directed at identification of the future development directions and formation tendencies of enterprises, engaged in production sphere (European Factories of the Future Research Association (EFFRA) Factories of the future FOF) [16]. The essence of the concept adopted by the European Union Commission is to provide recommendations of future enterprise's structure and activity. In this concept, manufacturing is indicated as the main condition for solution of major social problems. The importance of manufacturing potential of an enterprise is justified, and the directions for increasing the manufacturing capabilities of an enterprise are described.

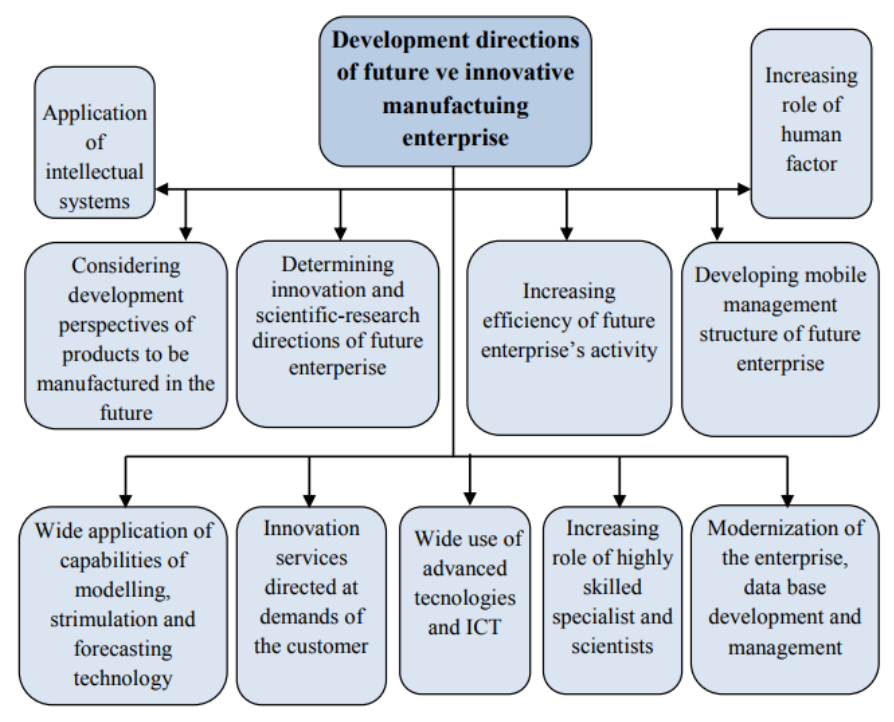

Fig.1. Development Directions of Future Innovative Manufacturing Enterprise

Specific directions were given priority in information map developed on the basis of the action plan of "Enterprise of future" (Figure 1) [16]. Several directions were included in the research priorities of enterprises of future, such as: 1)sustainable production (environmental safety, economic development, social safety), 
2)capabilities of ICT in intelligent manufacturing (intellectual, virtual and digital enterprises), 3)high-quality manufacturing (adaptive equipment, accurate manufacturing, tools of planning and modelling of manufacturing, non-waste technologies), 4)employment of new materials in production (science- and technology-intensive, small-scale) and etc. [17]. Overall, the solution of all social problems in Europe hinges on various factors. Hence, great attention is devoted to state-private sector cooperation at the level of European Union Commission. The primary goal of "Europe-2020" is the achievement of economic sustainability, the expansion of intellectual capacity and the comprehensive development [18-20]. For this purpose, the program of complex measure must be developed and carried out in various directions such as: 1)75\% of work force must be between 20-64 age years; 2)the increase of share of state and private sectors in investments devoted to regional development; 3)the achievement of favourable climate and energy changes; 4)the reduction of the level of environmental pollution; 5)the increase of energy volume obtained from renewable energy sources.

\section{Innovative Trends in State and Private Sector Cooperation}

The state and private sector cooperation must lead to the achievement of the same direction and same purpose of general and specific goals in the future. Until 2030, large-scale tendencies in the production, under the cooperation of state and private enterprises, must be considered (Figure 2). Several long-term broad trends are envisioned in "Vision for the future - 2030". Particularly, below-mentioned four long-term trends must be considered for the conduction of necessary integration of manufacturing process in Europe [21]:

1) The natural development of enterprise must be based on "green" and sustainable economy. The consumption of energy resources must be small-scale, clean and "green". Resource scarcity in manufacturing must be eliminated, the sustainability principle of employees and material assets must be followed in manufacturing processes [16].

2) Manufacturer must be in constant contact with consumer in the enterprise.

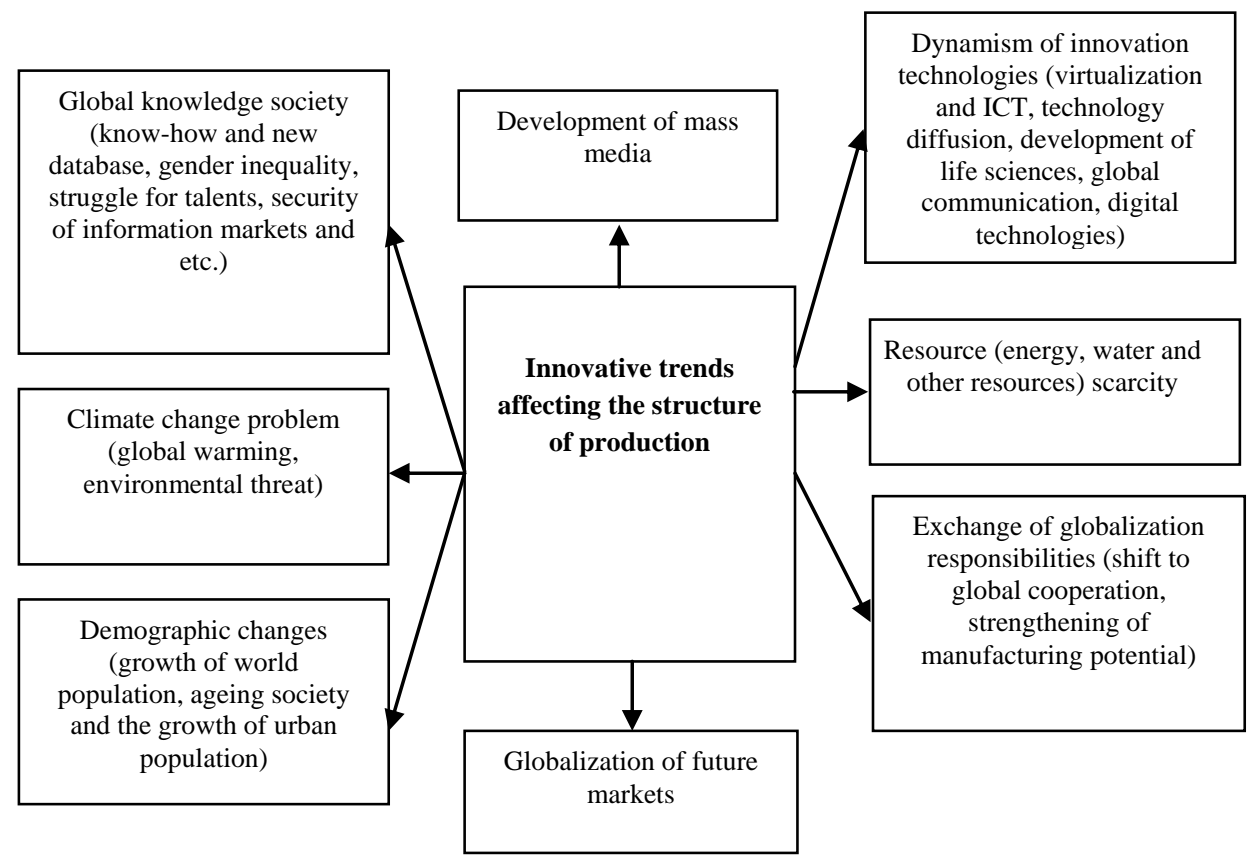

Fig.2. Innovative Tendencies Affecting the Structure of Manufacturing 
The manufacturing must be organized in accordance with interests and demand of corresponding cities and the surrounding districts, as well as the consumers. An enterprise must be integrated into the living environment. The measures oriented to manufacturing must be oriented to the integration of customers.

3) Enterprises must be chain wise linked. The main goal of manufacturing is the achievement of high level of competition (solid, flexible, rapid and changeable). European manufacturing system must consist of individual, design-oriented and mass-produced specific products. The integration of product and technological processes must be chain wise linked based on cooperation from simple to complex.

4) Brain centers must be established within enterprise. Employees must participate in the processes oriented to modelling and visualization. The role of ICT must be increased in product manufacturing, and the advancement of education level of workers with different degree of specialization. Work and wage system corresponding to decent living standards will lead to balanced regional development. The knowledge development will facilitate the high-level management of economic processes and financing. Those trends will substantially affect the structural changes in all fields of production.

\section{Opportunities and Problems of Enterprises of Future}

In general, as a result of interest, attention and care, oriented towards the concept of future development of enterprises, "Enterprise of future" International day is annually celebrated on the 19th of May. Recently, scientific-theoretical analysis and discussion of the concept of future development of enterprises has taken place in the scientific conference held in Warsaw (Poland) on 19th of May, 2015, with the participation of representatives of 71 countries [22]. This conference was organized by the European Network of Enterprises, National Center of Research and Development, European Research Program and other well-known international and regional organizations and scientific-research bodies. Regarding the broad trends of the Concept of Vision of the Future-2030, it can be mentioned that European manufacturing sector must go through innovative changes till 2030. For this purpose, the following must be established in high-priority scientific-research and innovative sectors: 1)advanced manufacturing processes, 2)adaptive and smart manufacturing systems, 3)electron, virtual and resource-efficient enterprises, 4)joint and mobile enterprises, 5)human-brain centered manufacturing, 6)customer-oriented manufacturing. Alongside with various issues, the prospects of ICT application in manufacturing were discussed in the conference dedicated to the prospects of implementation of ICT [17]. It was specifically mentioned that main capabilities of ICT are various and as following for improvement of manufacturing systems at different levels: 1) Intellectual enterprises must be modified in accordance with the requests of flexible manufacturing and customers. The goal of this process is to achieve the automatization, better control and the optimization of processes within an enterprise. Main tools include the use of program software, laser, intelligent technologies and etc. in construction of infrastructure of enterprises. The productivity of enterprise is carried out in different directions in such situation: 1) less waste, 2) less energy consumption, 3) reduction in time of market access, 4) quality improvement and etc. 2) Virtual enterprises pay attention to the global network of manufacturing and logistics, value generation, and the advancement of the efficiency of management of global manufacturing network. In order to provide the increase of product value, the efficient use of ICT, development of product and service systems, and the effective management of varying production situation must be achieved. One of the goals of this process is the management of procurement chains and the generation of new value by integrating goods and services. Process tools include the complex integration of program software, the management of distributed enterprise assets, as well as the development of new business models. 3) In digital enterprises, ICT is implemented during the design of larger production and management of product lifecycle, knowledge collection and management, the application of mutually conforming models for products and processes, design works, and the management of lifecycle. Primary tools include software, product testing, the processes till product manufacturing and utilization [23]. Regarding the production capabilities and problems of enterprises of future, it must be mentioned that the products of enterprise of future must be more competitive, environmentally clean and of 
high-quality. The production must possess economic, social and environmental sustainability for the manufacturing of such products. Main innovative manufacturing technologies and software systems must be developed and implemented in enterprises of future. Scientific-research and innovative priorities of an enterprise must be specified. Primary production processes of enterprise must be based on advanced tendencies and systems, and its effective organization on innovative scientific research.

\section{Management Technologies of the Performance of Enterprises of Future}

The priority must be given to the manufacturing of innovative products by means of development and application of specific control and monitoring systems, adaptive and intellectual systems during production processes[24-26].

The issues of development of diversification and modernization related to innovative structures, posed at international level from scientific-theoretical, technological and methodological point of view, facilitate the accurate specification of innovative criteria and parameters in management processes in those structures. This process creates new opportunities for the expansion of innovativeness, the selection of more favorable development options, and the efficient commercialization of scientific-research activities. The consideration of international and regional recommendations in new economic situation leads to the acceleration of integration processes and efficiency increase of the production-service processes [16].

In order to solve the problems of existing problems of future enterprises with help of innovation and ICT, the following must be taken into consideration: 1)cooperation in design, technology and services sectors, 2)security issues of information exchange, 3)monitoring of visual tracking of resource flow, 4)dynamic modification of orders, 5)detection of risk potential, 6)elimination of asymmetric distribution of information managing the lifecycle of final products, 7)consideration of complexity of resource provision. The application of cloud technologies and ICT tools is inescapable in enterprises of future. The rich practice existing in enterprises must be used, and the integration of real production resources must be carried out [27, 28]. Enterprises of future must also benefit from the most advanced technologies as digital, virtual and resource-saving, effective enterprises. It is necessary to employ intelligent systems for the advancement of reliability of manufacturing systems. A production cycle must be managed integratively in high-tech production enterprises. The monitoring and management of production, services and resources must be carried out in enterprises of future. Decisions must be made based on the analysis of high-level and competitive models for the improvement of product quality in enterprises. In some cases, production risks must be assessed and models of module type required for rapid adaptation of enterprises must be developed when necessary.

\section{Intellectualization of Management and Production Processes of Enterprises}

Development concept of enterprises takes into consideration the intellectualization of management, as well as production and services processes. Basically, automatization of production and services processes, and the application of intellectual system in that field, preconditions for the design management, intellectualization of planning, quality, services, diagnostics, procurement and etc. on intellectual grounds. Eventually, primary stages of management are carried out in intellectual form. Management of production processes based on new knowledge and technologies possesses specific features in accordance with the type of system and product, organizational structure, material reserves, information resources and systems. Several features such as technical and administrative management, processing of materials, services, support, security, innovative environment, automatization, program administration, various scalability, configuration capability, modernity and adaptivity pertain to production system [23, 29].

The application of automatization tools attracts broad attention in production systems particularly. Alongside with digital enterprises, digital products, engineering and management in digital environment, management of product lifecycle in global network environment, the application of intensive communication technologies in real-time period, intellectualization in production-procurement chain, ICT security and etc. problems are 
attempted to be resolved. High energy efficiency and productivity can be achieved by means of achievement of ergonomical human-computer interfaces, flexible management of working time, the integrity of science, education and training with support of ICT, scientific modelling of the process, development of individual production solutions, the flexibility of marketing process and the application of distant production and intellectual technologies [17]. Several primary aspects must be considered for the management of the role of human and work place in innovative enterprises of future [16, 31, 32]: 1) how people work and learn; 2) mutual relations of humans with technology; 3 ) human contribution to production value and etc. (Figure 3 ).

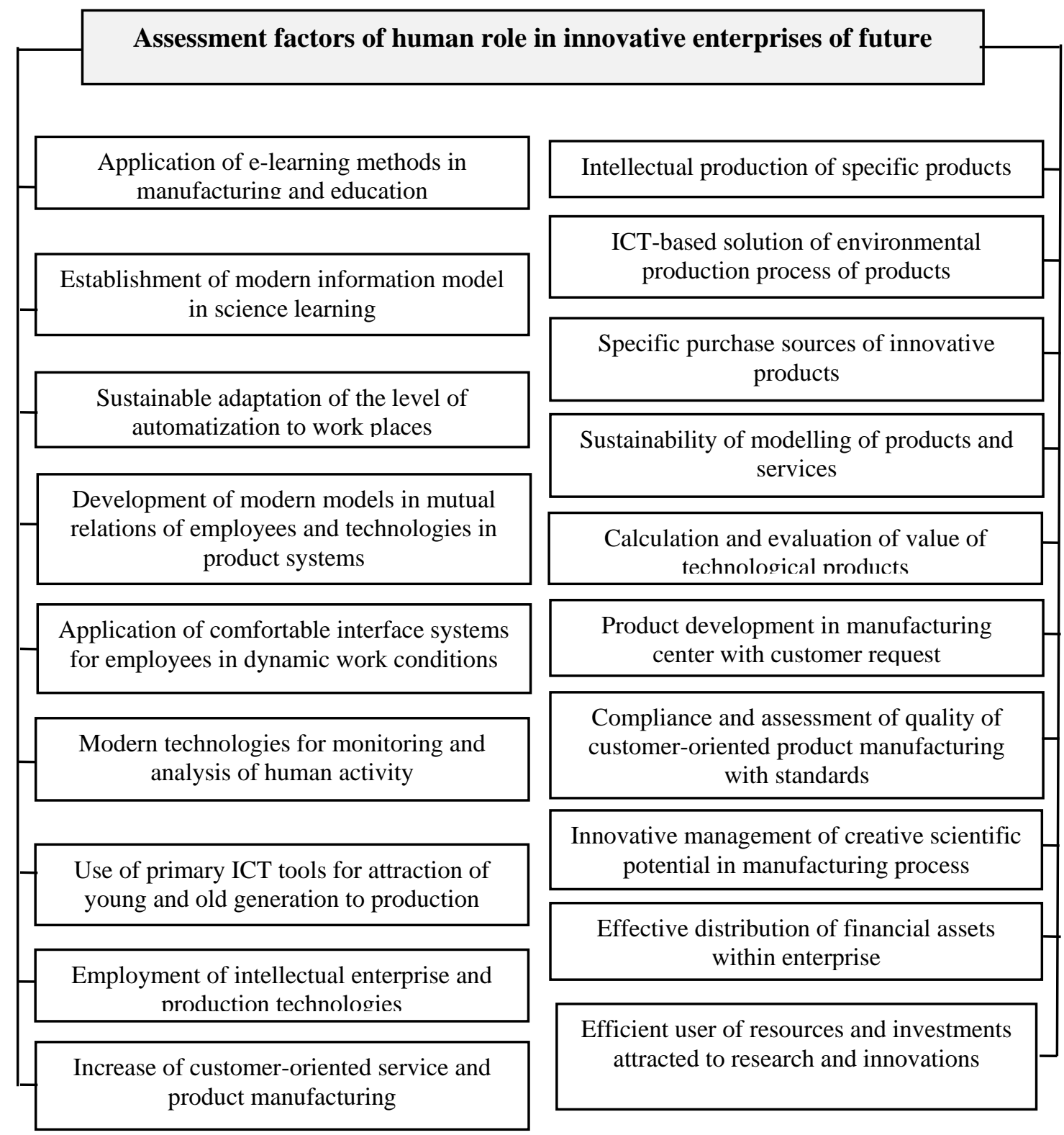

Fig.3. Assessment Factors of Human Role in Innovative Enterprises of Future 
The development of strategic management system, management of technological manufacturing, enterprise and management of production system, development and management of enterprise's strategy, and necessary integration of existing tools and methods must be implemented for comprehensive and mobile management of enterprise and resources. The following can be attributed to the main outcomes expected in automatization and intellectualization of production processes [17, 30]: 1) direct economic impact on innovations and research in production; 2) support for development of small and medium enterprises; 3) support for conduction of scientific results applied in several industrial sectors; 5) manufacturing of a market-competitive product; 6) enterprise of cooperation among scientific and industrial fields; 7) orientation towards European manufacturing, enterprise of tight links with regional clusters; 8) the increase in share of sales of European manufacturing equipment; 9) the achievement of environmental and economic privileges due to the use of new technologies and etc.

The efficiency of innovative enterprises can be achieved through the acceleration of the formation of intellectual and creative human potential, the increase of effectiveness of the structure and dynamics of innovative personnel potential, advancement of professional staff training, intellectualization of the level of management of human resources, the provision of participation of experts in conduction of scientificinnovative research, and the increase of the participation level of human potential in innovative management of enterprise performance and decision-making by developing social-cultural and public activities of human resources.

\section{Conclusion}

The economic development of a country in modern world is mostly achieved through innovations. Therefore, one of the primary goals of the government is considered to be the enterprise of innovative structure of new type which is the driving force of economic development. There are national strategies and state programs determining the specific aspects of any country's development directions in a specific situation. According to their duties strategic principles, goals, obligations, priorities are shown. Alongside, many works must be carried out regarding the formation and implementation of action mechanisms of those structures. Various strategic principles and priorities existing in international practice are generalized being synthesized in this direction. The goals of enterprise of innovative bodies and the base principles of their performance must be determined. Organizational, functional forms, features, as well as the main characteristics of those have been noted. In innovative bodies, the issues such as the implementation forms and types of innovations, innovation stages and periodicity are clarified. Corresponding recommendations are given regarding the development and implementation of modern management mechanisms and systems. As observed, the issues of development of diversification and modernization related to innovative structures, posed at international level from scientifictheoretical, technological and methodological point of view, facilitate the accurate specification of innovative criteria and parameters in management processes in those structures. This process creates new opportunities for the expansion of innovativeness, the selection of more favorable development options, and the efficient commercialization of scientific-research activities. The consideration of international and regional recommendations in new economic situation leads to the acceleration of integration processes and efficiency increase of the production-service processes.

The following must be taken into consideration during the manufacturing of adaptive and smart manufacturing devices, system parts and equipment in the innovative structures formed on the basis of modern technologies: 1)technologies and robots with dynamically changing configuration, 2)stepwise formation of creative mind in support for the use of technologies and robots, 3)the maintenance of safety in technology and robot manufacturing and the enterprise of necessary cooperation for mutual links of production, 4)the use of smart technologies and robots in expansion of flexible manufacturing, 5)maintenance of new technologies with effective structure of adaptive and developing enterprises, 6)effective use of manufacturing machines with new structure and resources necessary for high-tech manufacturing, 7)application of nano-technologies in maintenance of precision of micro- and macro-manufacturing equipment, 8)achievement of high production by 
using modern technology and efficient resources in manufacturing, 9)application of multidisciplinary technology in manufacturing and services. In order to achieve dynamic development in manufacturing enterprises, the automatization of enterprise manufacturing must be carried out. For this purpose, formation of dynamic, flexible and intelligent management systems is required for the management of manufacturing. At the same time, monitoring system must be established in manufacturing.

\section{Reference}

[1] Musayev A.F. Innovation economy and tax stimulation. Baku. “Azerbaycan Universiteti” Press, 2014. $184 \mathrm{p}$.

[2] Alguliyev R.M., Aliyev A.G., Shahverdiyeva R.O. The content of innovations and structural analysis of their features in the formation of information economy // Life Science Journal 2014,11(12), p. 119-125.

[3] United Nations University. Maastricht Economic and Social Research Institute on Innovation and Technology, http://www.merit.unu.edu

[4] Lidong Wang, Guanghui Wang. Big Data in Cyber-Physical Systems, Digital Manufacturing and Industry 4.0. International Journal of Engineering and Manufacturing (IJEM), 2016, pp.1-8.

[5] United Nations Conference on Trade and Development, http://unctad.org/en/

[6] http://www.economy.gov.az

[7] United Nations Development Program, http://www.undp.org/innovation2014

[8] International Association of Organizational Innovation, http://www.iaoiusa.org

[9] P. Sreeramana Aithal, Shubhrajyotsna Aithal. Nanotechnology Innovations and CommercializationOpportunities, Challenges \& Reasons for Delay. International Journal of Engineering and Manufacturing (IJEM), 2016, pp.15-25.

[10] Association for the Transfer of Technology, Innovation and Industrial Information, http://www.tii.org

[11] International Association of Scientific Innovation and Research, http://www.iasir.net

[12] Research and Technical Association "Technopol-Moscow" http://www.technopolmoscow.com/ru

[13] International Association of Science Parks and Areas of Innovation, http://www.iasp.ws

[14] World Alliance for Innovation. http://www.wainova.org

[15] National Business Incubation Association (NBIA), https://www.inbia.org

[16] European Commission. Factories of the future multi-annual roadmap for the contractual PPP under Horizon 2020. Prepared by: European Factories of the Future Research Association (EFFRA) a Manufuture İnitiative, http://www.ec.europe.eu European Technology Platform (ETP) for Future Manufacturing Technologies: ManuFuture, http://www.manufuture.org/manufacturing

[17] Sibalija T. Intelligent Manufacturing: Challenges and Trends / Conference Factories of Future for Thailand, Bangkok, 15-16 January 2013, pp. 2-5.

[18] European Commission Innovation Union - A pocket guide on a Europe 2020 initiative. Research and Innovation, Luxembourg, Publications Office of the European Union, 2013, 16 p. 19.

[19] Digital Agenda in the Europe 2020 strategy, https://www.ec.europa.eu/digital-agenda/en/digital-agendaeurope-2020-strategy

[20] Enterprise Europe Network, http://www.effra.eu

[21] Peltomaki A. Innovation in European Manufacturing. Manufuture 2013. View on Horizon 2020: sustainable re-industrialisation of Europe / European conference for Engineering industry and research, Vilnius, 6-8 october 2013, pp.37-39.

[22] International Networking Day on Factories of the Future and H2020 "Factories of the Future" Brokerage Event, Warsaw, 19 May 2015, http://www.fof2015.eu

[23] Westkämper E. Digital and Smart Factories. Manufuture 2013. View on Horizon 2020: sustainable reindustrialisation of Europe / European conference for Engineering industry and research, Vilnius, 6-8 october 2013, pp. 115-118. 
[24] Musher S.L. Collaboration in Manufacturing through Collaboration in Innovation. Manufuture 2013. View on Horizon 2020: sustainable re-industrialisation of Europe / European conference for Engineering industry and research, Vilnius, 6-8 october 2013, pp. 43-46.

[25] Herbert B.V. The role of Manufacturing for the European Economy / Manufuture 2011 conference. "West and East Europe in global High Added Value manufacturing - facts of today and challenges of tomorrow", Wroclaw, 24-25 October 2011, pp. 7-9.

[26] Francesco J. European Innovation Partnership - New Industry / Manufuture 2011 conference. "West and East Europe in global High Added Value manufacturing - facts of today and challenges of tomorrow”, Wroclaw, 24t -25 October 2011, pp.31-32.

[27] Zhang L., Jingeng M., Huntsinger R.C. Future Manufacturing Industry with Cloud Manufacturing / Cloud-Based Design and Manufacturing (CBDM), 2014, pp. 127-152.

[28] Marenco C. Building an Excellent Science Base in Manufacturing. Manufuture 2013. View on Horizon 2020: sustainable re-industrialisation of Europe / European conference for Engineering industry and research, Vilnius, 6-8 october 2013, pp.31-33.

[29] Nureni Asafe Yekini, Uduak Inyang-Udoh, Funmilayo Doherty. Open educational resources (oer) for sustainable development using autonomic cloud computing system. International Journal of Engineering and Manufacturing (IJEM), 2016, pp.60-68 -11-08.

[30] Aminuddin S.A., Nawawi M.K., Kalmoun E.M. Green manufacturing management: investigation of the philosophy practised in industry / 26th International Conference on CAD/CAM, Robotics and Factories of the Future, Kuala Lumpur, 26-28 July 2011, pp.841-846.

[31] Borisov V.N., Pochukaeva O.V. Modernizations of Russian manufacturing on the basis of the sustainable development of domestic machine building // Journal Studies on Russian Economic Development, vol. 22, issue 2, pp. 142-147.

[32] A.G.Aliyev, R.O.Shahverdiyeva. Structural analysis of the transformation processes of scientific and technical ideas and knowledge into innovations in technoparks. International Journal of Engineering and Manufacturing (IJEM), 2017, pp.1-10.

\section{Authors' Profiles}

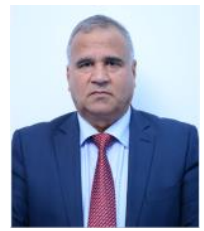

Ph.D. in economics, ass. professor Alovsat Aliyev (born January 8, 1956). Head of department of the Institute of Information Technology of Azerbaijan National Academy of Sciences. He has a total number of 150 scientific articles and 5 books. Alovsat Aliyev continues to conduct scientific-research works and deals with issues such as characteristics of ICT application in economical processes and management authorities, information problems in social-economical systems, scientific-theoretical basics of formation of information society, information economy, determination of demonstrative systems in ICT field, research of reasons of establishment of digital differences in the society, study economical basics, problems of informatization of humanitarian fields, humanitarian aspects of ICT.

Areas of interest: innovative information and knowledge economy, technopark, green economy, computers and information science, econometrics.

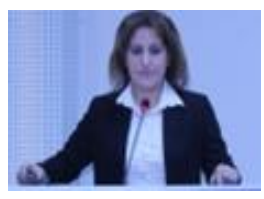

Senior scientist of the Institute of Information Technology of Azerbaijan National Academy of Sciences. She has a total number of 38 scientific articles. Her articles dedicated to actual ICT problems, innovation economy, technoparks, are regularly published in various scientific journals and newspapers.

Areas of interest: information systems, process of innovation, technopark, management. 
How to cite this paper: Alovsat Garaja Aliyev, Roza Ordukhan Shahverdiyeva,"Perspective Directions of Development of Innovative Structures on the Basis of Modern Technologies", International Journal of Engineering and Manufacturing(IJEM), Vol.8, No.4, pp.1-12, 2018.DOI: 10.5815/ijem.2018.04.01 